\title{
Kamuda İstihdam İstek ve Baskısının Girişimcilik Eğilimi Üzerine Etkisinin Belirlenmesi: Kalitatif Bir Analiz*
}

Fatih Mehmet DEMIR ${ }^{1}$

Ali YILDIZ ${ }^{2}$ Aytekin FIRAT ${ }^{3}$

\section{Öz}

Kamuda istihdam edilme beklentisinin ötesinde, sahip olduğu nitelikler ile kendi ayaklart üzerinde durabilecek girişimlerde bulunabilme eğiliminde olan gençlerin sayısının artması, bir ülke için büyük kazanç olacaktır. Gençlerin kariyer planlarını, kendi istekleri veya anne, baba ya da diğer yakınlarının baskısı ile kamuda istihdam edilme üzerine kurmalarının, girişimciliğin yaygınlaşmasının önündeki engellerden biri olduğu söylenebilir. Bu çalışma, kamuda istihdam edilme isteğinin veya baskısının gençlerin girişsimcilik eğilimleri üzerinde etkisinin olup olmadığını belirlemek amacıyla yapılmıştır. Bu amaç doğrultusunda Muğla Sitkı Koçman Üniversitesi Sağllk Hizmetleri Meslek Yüksekokulu'nda ĕgitim gören öğrenciler ile derinlemesine mülakat yöntemi ile görüşülmüştür. Yarı yapılandırılmış görüşsme formuyla detaylı verilerin elde edildiği mülakatlar içerik analizi ile incelenerek değerlendirilmişstir. Araşstırmada elde edilen sonuçlara göre kamuda istihdam edilme yönündeki aile baskısının, gençlerin girişimcilik eğilimleri üzerinde olumsuz yönde etkisinin olduğu belirlenmiştir.

Anahtar Kelimeler: Girişimcilik, Girişimcilik Eğilimi, Kamu İstihdamı, Kalitatif Araştırma.

\section{Determination of the Effect of Public Employment Request and Pressure on Entrepreneurship Tendency: A Qualitative Analysis}

\begin{abstract}
Beyond the expectation of employment in public, an increase in the number of young people who are inclined to be able to take initiatives on their own feet with the qualities they possess will be a great gain for a country. One of the obstacles to the spread of entrepreneurship is the fact that young people build their career plans on their own will or on the employment of the public with the pressure of their mother, father or other relatives. This study was conducted to determine whether the desire or pressure of public employment has an effect on the entrepreneurship tendencies of young people. For this purpose, in-depth interviews were conducted with students studying at Muğla Sttkr Koçman University Vocational School of Health Services. Interviews in which detailed data were obtained through semi-structured interview form were examined and evaluated by content analysis. According to the results of the study, family pressure on employment in the public sector has a negative effect on the entrepreneurship tendencies of the youth.
\end{abstract}

Keywords: Entrepreneurship, Entrepreneurship Tendency, Public Employment, Qualitative Research.

\footnotetext{
* Bu çalışma, 17-20 Ekim 2019 tarihinde Bodrum/Muğla'da düzenlenen 4. Uluslararası Girişimcilik, İstihdam ve Kariyer Kongresi'nde bildiri olarak sunulmuştur.

1 ORCID Dr. Öğr. Üyesi, Muğla Sttkı Koçman Üniversitesi, SHMYO, Tıbbi Hizmetler ve Teknikler Bölümü, fdemir@mu.edu.tr

2 ORCID Dr. Öğr. Üyesi, Muğla Sıtkı Koçman Üniversitesi, Seydikemer Uygulamalı Bilimler Yüksekokulu, Muhasebe ve Finansal Yönetim Bölümü, aliyildiz@mu.edu.tr

3 ORCID Doç. Dr., Muğla Sıtkı Koçman Üniversitesi, İIBB, İşletme Bölümü, aytekinfirat@mu.edu.tr
} 


\section{EXTENDED ABSTRACT}

Having a young population, the structural characteristics of the labor market is seen that Turkey is faced with a situation arising in unemployment is examined. The fact that entrepreneurship has the potential to create employment for young people, in addition to the economic and social aspects of micro and macro scale, has led the issue of entrepreneurship to be handled as necessary in our country in recent years. However, it can be said that young people's career plans are based on their own wishes or the pressure of their parents, or other relatives on employment in the public, which is one of the obstacles to the expansion of entrepreneurship.

This study was conducted to determine whether the desire or pressure to be employed in the public has an impact on entrepreneurship tendencies of young people. For this purpose, in-depth interview method was interviewed with students studying at Muğla Sitkı Koçman University Health Services Vocational School. Interviews, in which detailed data were obtained through semi-structured interview form, were examined and evaluated by content analysis.

In this study, in which qualitative research approach was adopted, in-depth interview method, one of the qualitative data collection methods, was used. The fact that the findings, which are accepted as an important constraint of qualitative research in social sciences, cannot be generalized, is also valid for this study. However, in this study, it is predicted that qualitative methods can provide more effective results than quantitative methods to understand and interpret the entrepreneurship tendencies and career planning processes of young people. In addition, in the literature review, the fact that there is no research related to the issues of public employment and entrepreneurship tendency increases the importance of this study with its exploratory aspect.

According to the results of the study, it is seen that the education they receive can lead individuals to entrepreneurship and there may be differences in entrepreneurship tendencies according to the field in which university students are trained. This result, which is similar to the results of the research in the literature, shows that a relationship can be established between the field in which young people are educated and their entrepreneurship tendencies.

$71.6 \%$ of the participants stated that at least one of their mothers, fathers or other relatives had influence and guidance on their choice of profession. Accordingly, it can be concluded that the parents, parents and other relatives have an important influence on the career choices and career plans of the youth.

27 out of 33 participants who stated that they want to work in the public sector declared that they want to work in the public sector, with their parents or other relatives' directions directed mainly to work in the public sector. It is seen that young people who plan their career on public employment are mainly affected by the direction of their relatives.

In this case, it does not seem possible for young people to decide to be entrepreneurs on their own. Everyone in the employment of the public as a country encouraged by their close family members is not possible for young people to be able to establish their own business in Turkey is emerging importance of the material and spiritual encouragement. 


\section{Giriş}

Girişimcilik konusunun ekonomik ve sosyal açıdan bir ülke için önemi, sanayi devriminden itibaren günümüze kadar güncelliğini korumaktadır. Yeni mal ve hizmet üretilmesini sağlayarak ürün çeşitliliğini sağlaması, yeni üretim yöntemlerinin geliştirilmesini sağlaması, yeni pazarlar bulmayı ve satış yöntemlerinin oluşturulmasına katkısı, yeni kaynaklara ve hammaddeye ulaşım sağlaması, rekabet yoluyla piyasadaki etkinliği attırması, serbest piyasa işleyişine ve gelir dağılımının düzelmesine katkısı, istihdam oluşturma potansiyeli, sermaye birikimi sağlaması, endüstride yeni organizasyonlar kurma potansiyeli, refah düzeyinin yükseltilmesine katkısı, bölgesel gelişmişlik farklarının ortadan kaldırılmasını sağlaması girişimciliğin ekonomik fonksiyonlarıdır. Toplumda neden olduğu değişim ve topluma kazandırdığı dinamizm yanında özellikle sosyal sorumluluk projelerinin sahiplenilmesiyle girişimcilik statüsünün getirmiş olduğu toplumsal prestij ise girişimciliğin sosyal fonksiyonlarıdır (Marangoz, 2016:86-93).

Genç bir nüfusa sahip olan Türkiye'nin işgücü piyasasının yapısal özellikleri incelendiğinde işsizlik olarak ortaya çıkan bir durumla karşı karşıya olduğu görülmektedir. Girişimciliğin ekonomik ve sosyal açıdan mikro ve makro ölçekli faydaları yanında özellikle gençler için istihdam oluşturma potansiyeli taşıması, girişimcilik konusunun son yıllarda ülkemizde de gerekli olduğu şekilde ele alınmaya başlamasına neden olmuştur. Girişimcilerin iş kurma ve yürütme konularında bilgi ve becerilerini geliştirmek, başarılı iş planlarını/iş modellerini ödüllendirmek, girişimcilik ekosisteminde yer alan aktörler arası işbirliğini arttırmak, yeni kurulan işletmelerin en kırılgan oldukları dönemde hayatta kalma oranının arttırılmasına katkı sağlayacak yapıların ve ulusal plan ve programlar doğrultusunda yeni işletmelerin kurulmasını ve sürdürülmesini sağlamak amacıyla, Küçük ve Orta Ölçekli İşletmeleri Geliştirme ve Destekleme İdaresi Başkanlığı (KOSGEB) tarafından yürütülen girişimciliği geliştirme ve destek programları, bu konuda atılmış önemli adımlara örnek olarak verilebilir.

Sahip olduğu nitelikler ile kendi ayakları üzerinde durabilecek girişimlerde bulunabilme eğiliminde olan gençlerin sayısının artması, bir ülke için büyük kazanç olacaktır. Ancak gençlerin kariyer planlarını, kendi istekleri veya anne, baba ya da diğer yakınlarının baskısı ile kamuda istihdam edilme üzerine kurmalarının, girişimciliğin yaygınlaşmasının önündeki engellerden biri olduğu söylenebilir. Bu nedenle bu çalışma, kamuda istihdam edilme isteğinin veya baskısının gençlerin girişimcilik eğilimleri üzerinde etkisinin olup olmadığını belirlemek amaciyla yapılmıştır.

Nitel araştırma yaklaşımının benimsendiği bu çalışmada, kalitatif veri toplama yöntemlerinden olan derinlemesine mülakat yöntemi kullanılmıştır. Sosyal bilimlerde kalitatif araştırmaların önemli bir kısıtı olarak kabul edilen bulguların genellenememesi, bu çalışma için de söz konusudur. Ancak bu çalışmada kalitatif yöntemlerin gençlerin girişimcilik eğilimlerini ve kariyer planlama süreçlerini anlamak ve yorumlamak için kantitatif yöntemlerden daha etkili sonuçlar sunabileceği öngörülmüştür. Bunun yanında yapılan literatür taramasında, kamuda istihdam isteği ile girişimcilik eğilimi konularının ilişkilendirildiği herhangi bir araştırmaya rastlanılmaması bu çalışmanın keşfedici yönüyle önemini arttırmaktadır.

\section{Kavramsal Çerçeve}

\subsection{Girişimcilik Eğilimi}

Girişimcilik eğiliminde olan bir bireyin, zihinsel bir süreç içinde iş planını geliştirme ve uygulama yönünde gayret ve bağl1lık gösteren birey olduğunu ifade etmek mümkündür (Basım 
ve Şeşen, 2012:22). Tüm çalışanlardan, işletmelerden ve kurumlardan sürekli yenilik talebinin söz konusu olduğu bu dönemde var olan yenilik talebini karşılayacak olanların, hangi sektör veya alanda olursa olsun girişimcilik eğiliminde olan insanlar olduğu söylenebilir. Girişimcilik üzerine yapılan araştırmalarda genel olarak üzerinde durulan araştırma sorularının başında kişilerin niçin girişimci oldukları ya da girişimci olan kişilerin hangi özelliklere sahip oldukları gelmektedir. Her insanın girişimde bulunmaması veya her girişimin başarılı olmaması bu araştırma sorularına haklı gerekçeler oluşturmaktadır.

Yaşanılan süreçte girişimcilik eğiliminin başlangıç noktasının gerek kişisel gerekse örgütsel düzeyde değişime duyulan ihtiyacın olduğu söylenebilir (Top, 2008:32). Çevrenin sürekli değişmesi sonucu ihtiyaç duyulan değişim, kısaca işlerin farklı biçimde yapılmasıdır (Can ve diğ., 2006:447). İşlerin alışılagelmişin dışında farklı yapılması doğal olarak hem risk faktörünü hem de yenilik faktörünü ortaya çıkarır. Bu durumda yaşanılan çevredeki değişimi fark edenler, çevrede yaşanılan değişim nedeniyle kişisel veya kurumsal düzeyde değişmek zorunda olduğunun farkında olanlar, değişim süreci sonucu elde edilecek olan yeniliğin avantajlarından faydalanmak isteyenler, bu değişim sürecinin beraberinde getirdiği riski göze alabilenler, girişimcilik eğiliminde olan kişilerdir.

Literatürde girişimciliği etkileyen faktörlerin, farklı başlıklar altında tanımlandığı ve gruplandırıldığı görülmektedir. Genel olarak bakıldığında girişimciliğin ekonomik, toplumsal, kültürel ve kişisel faktörlerden etkilendiğini söylemek mümkündür (Börü, 2006:19). Güçlü, istikrarlı ve girişimciliğin desteklendiği bir ekonomik ortam, girişimciler için kolaylaştırıcı uygun zemin oluşturmaktadır. Kişilerin sosyal çevresi ve özellikle aile yapıları girişimciliği teşvik edici, kısıtlayıcı veya kararsızlık oluşturucu etkide bulunabilmektedir (İraz, 2010:164). Ait olduğu toplumun tüm ilişki ve etkileşim süreçlerine tesir eden toplumsal kültürel koşullar, girişimci güdüler, girişimci birey ve kültür kalıpları üretebilmektedirler. Çünkü kültür, toplum üyeleri için genel davranış düzlemi oluşturmakta ve risk alma, belirsizlikten kaçınma, değişime direnç gösterme, yeniliklere karşı tavır takınma davranışlarında belirleyici ve yönlendirici bir rol oynamaktadır (Aytaç ve İlhan, 2007:109-110). Bireylerin sahip oldukları bir takım kişisel özellikler ise girişimcilik üzerinde olumlu ya da olumsuz etkiye sahiptir. Bu özelliklerin birey üzerindeki olumlu etkisi, bu kişilerin girişimciliğe yatkınlığının kastedildiği, örneğin "ekmeğini taştan çıkarır" gibi cümlelerle diğer bireyler tarafından halk arasında sıklıkla ifade edilir. Girişimcilik üzerinde etkisi olan bireysel özelliklerin büyük çoğunluğunun doğuştan kazanıldığg ifade edilse de çevresel faktörlerin ve eğitimin kişisel özellikleri ortaya çıkarmada büyük etkisinin bulunduğu ve önemli bir bölümünün öğrenilebilir ve geliştirilebilir davranışlar olduğu bilinmektedir (Börü, 2006:22).

Başarılı bir girişimcide bulunması gereken ve literatürde üzerinde sıcça durulan temel kişilik özelliklerini, aşağıdaki gibi sıralamak mümkündür (akt. Bozkurt ve Erdurur, 2013:5961):

- Başarma ihtiyacı duyma: Girişimciliğin en yaygın belirleyicilerinden olduğu kabul edilen başarma ihtiyacı duymak, insan davranışının ardındaki itici güç ve girişimci davranışını etkileyen güçlü bir psikolojik faktör olarak ele alınmıştır.

- Kontrol odağı: Kişinin kendi eylemleri ve bu eylemlerinin sonuçlarının arasındaki bağlantı gücünü ne şekilde algıladığını yansıtan bir değişken olarak kabul edilen kontrol odağı, kişinin yaşamı hakkındaki algılarını ve yaşamındaki olayları kontrol edip edemeyeceğine olan inancını temsil eder. İnsanların kendi yaşamlarını denetleyebilmeleri bakımından bazı insanlar yapmak istedikleri davranışlar için gerekli gücü kendilerinde gördüklerini inanırlarken bazı insanlar bunların dış etkenlere bağlı olduğuna inanırlar. 
- Risk alma: Girişimcilerin önemli kişilik özelliklerinden birisi olarak kabul edilen risk almanın, sonuçların ne olacağını bilmeden, bilinmeyen bir bölgede ya da bilinmeyen koşullarda karar vermeyi ifade etmektedir. Birçok çalışmada, girişimci olanların olmayanlara göre daha fazla risk aldıkları belirtilmiştir.

- Belirsizlik toleransı: Bir durum için yeterli bilgi olmadığında belirsizlik var demektir ve bu durum, yeterli ipuçlarının eksikliği nedeniyle yeterince yapılandırılmamış veya birey tarafından kategorize edilmemiş olaylar şeklinde ifade edilir. Belirsizlik toleransı ise belirsiz durumlarda kişinin olumlu cevap verme yeteneğidir. Girişimciler belirsizlikler ve zorluklarla karşılaştıklarında pes etmeyip çabalarında 1srarlı olan kişilerdir.

- Kendine güven: Bireylerin bir işteki sorumluluğunun üstesinden gelmesini sağlayacak ve ihtiyaç duyduğu yeteneğe sahip olduklarına dair inancı ifade eden kendine güven, sayısız zorluk ve belirsizlikle karşı karşıya olan girişimcilerin yeteneklerini etkileyerek başarılı olmalarına yardımcı olur.

- Yenilikçilik: Fırsatları değerlendirmek, mevcut teknolojiyi geliştirmek ve pratik bir şekilde kullanmayı sağlamak olan yenilikçilik, ayrıca fırsatların ve ticarileştirilmiş ürünlerin yeni süreçlerle uygulanmasıdır. Schumpeter (1934)'e göre yenilikçilik, girişimciliğin odak noktasıdır.

Üniversite öğrencilerinin girişimci kişilik özellikleri ile girişimcilik eğilimleri arasındaki ilişkiye yönelik olarak literatürde birçok çalışma bulunmaktadır. Ancak kamuda istihdam isteği ile girişimcilik eğilimi konularının ilişkilendirildiği herhangi bir araştırma bulunamamıştır. $\mathrm{Bu}$ çalışmalarda çoğunlukla girişimcilik eğiliminde olan öğrencilerin, olmayan öğrencilere göre daha farklı kişilik özelliklerine sahip oldukları ifade edilmektedir. Örneğin Koh (1996) tarafından lisansüstü eğitim alan üniversite öğrencilerinden girişimcilik eğiliminde olanların, olmayanlara göre daha fazla yenilikçilik, belirsizliğe tolerans ve risk alma özellikleri taşıdığı savunulmaktadır. Türkiye' deki bir vakıf üniversitesinin öğrencilerinin girişimcilik eğilimleri üzerine yürütülen bir çalışmada Çolakoğlu ve Gözükara (2016) tarafından, girişimci eğiliminde olan öğrencilerin olmayanlara göre daha fazla yenilikçi oldukları, daha fazla başarıya ve daha fazla iç kontrol odağına ihtiyaç duydukları belirlenmiştir. Bozkurt ve Erdurur (2013) tarafından yürütülen başka bir çalışmada ise üniversite öğrencilerinin girişimci kişilik özelliklerinin kendine güven boyutu dışındaki başarma ihtiyacı duyma, kontrol odağı, risk alma, belirsizlik toleransı ve yenilikçilik boyutlarının, girişimcilik eğilimleri üzerinde pozitif yönde anlamlı ilişkisinin olduğu belirlenmiştir.

Literatürde bireylerin ailesi ve yakın çevresi ile ilgili birtakım özellikler (çocuk sayısı, bireyin kaçıncı çocuk olduğu, ailedeki diğer bireylerin işi ve aylık kazancı vb.) ve aileden sağlanan tecrübe ve maddi desteğin, bireylerin girişimcilik eğilimi üzerindeki etkisini konu alan çalışmalar da bulunmaktadır. Gurel ve diğ. (2010) tarafından turizm alanında eğitim gören öğrenciler üzerinde yapılan araştırmada, özellikle aileden sağlanan tecrübe, teşvik ve maddi desteğin bireyin kendi işini kurması konusundaki niyetini, önemli ölçüde etkilediği ortaya konulmuştur. Korkmaz (2012) tarafından üniversite öğrencilerinin kendilerini girişimci bir kişiliğe sahip görmelerinde ve gelecekte iş kurma isteklerinde etkili olan psikolojik, demografik ve aile özellikleri arasında anlamlı ilişkiler olduğu belirlenmiştir. Aksel ve Bağcı (2016) tarafından ise üniversite öğrencilerinin girişimcilik eğilimleri konusunda, erkek öğrencilerin kız öğrencilere göre ve 24-26 yaş grubundaki öğrencilerin diğer gruplardaki öğrencilere göre girişimcilik eğilimlerinin daha fazla olduğu ortaya konulmuştur. Benzer şekilde Kılıç ve diğ. (2012) tarafından üniversite öğrencilerinin girişimcilik eğilimleri üzerine yürütülen bir çalışmada da öğrencilerin cinsiyet, aylık gelir gibi demografik özellikleri ile girişimci kişilik özellikleri arasında anlamlı farklılıkların olduğu belirlenmiştir. Bazı çalışmalarda ise (Yılmaz 
ve Sünbül, 2009) k1z ve erkek üniversite öğrencilerinin girişimcilik düzeylerinde anlamlı farklılığın bulunmadığı belirtilmiştir.

Literatürde, aldıkları eğitimin bireyleri girişimciliğe yönlendirebileceğine ve eğitim görülen alan ile girişimcilik eğilimi arasında ilişki kurulabileceğine dair çalışmalar da bulunmaktadır. Örneğin Marangoz ve diğg. (2013) tarafından yapılan araştırmada, üniversite öğrencilerinin eğitim gördükleri alana göre girişimcilik eğilimlerinin bazı alt boyutlarında farklılıklar belirlenmiştir.

\subsection{Kamuda İstihdam}

Genel anlamda işgücünün çalışması ve çalıştırılması olarak ifade edilen istihdam, referans dönemde iş başında olanlar (en az bir saat çalışmış olsa dahi) ve şu an iş başında olmasalar da iş ile bağlantısı kesilmemiş olanlar olarak tanımlanmaktadır (Akgün ve Akgün, 2017:3). Birçok gelişmiş ülkeye göre genç bir nüfusa sahip olan Türkiye'nin işgücü piyasasının yapısal özellikleri incelendiğinde, işgücü (emek) arzının, işgücü (emek) talebine göre fazlalığından kaynaklanan ve işsizlik olarak ortaya çıkan bir durumla karşı karşıya olduğu görülmektedir.

Tablo 1: Yıllara Göre Türkiye'deki İstihdam Rakamları

\begin{tabular}{|c|c|c|}
\hline YILLAR & $\begin{array}{c}\text { İSTIHDAM } \\
\text { EDİEN } \\
\text { TOPLAM Kişi } \\
\text { SAYISI (Bin Kişi) }\end{array}$ & $\begin{array}{c}\text { ISTİHDAM } \\
\text { ORANI }\end{array}$ \\
\hline 2010 & 21.858 & 41,3 \\
\hline 2011 & 23.266 & 43,1 \\
\hline 2012 & 23.937 & 43,6 \\
\hline 2013 & 24.601 & 43,9 \\
\hline 2014 & 25.933 & 45,5 \\
\hline 2015 & 26.621 & 46,0 \\
\hline 2016 & 27.205 & 46,3 \\
\hline 2017 & 28.189 & 47,1 \\
\hline 2018 & 28.738 & 47,4 \\
\hline 2019 & 28.080 & 45,7 \\
\hline
\end{tabular}

Kaynak: http:// www.tuik.gov.tr (Erişim Tarihi: 22.03.2020)

İstihdamın itici gücü olan ekonomik büyümenin de etkisi ile Türkiye'nin son 10 yıldaki istihdam oluşturma potansiyelinin seyri, Tablo 1'de görüldüğ̈̈ gibidir. Türkiye İstatistik Kurumu'nun Mart 2020'de yayınlamış olduğu verilere göre işgücüne katılma oranı, 2019 yılında bir önceki yıla göre 0,2 puan azalarak \%53 olarak gerçekleşmiştir. İstihdam oranı ise aynı dönem için \%45,7 olarak gerçekleşmiş ve işsizlik oranı bir önceki yıla göre 2,7 puanlık artışla \%13,7 seviyesine yükselmiştir. Özellikle genç işsizlik olarak tanımlanan 15-24 yaş aralığındaki kişilerin işsizlik oranının ise \%5,1 gibi daha yüksek bir artışla \%25,4 seviyesine ulaştığı görülmektedir.

2019 yılında toplam kamu istihdamı 2018 yılına göre \%6,7 oranında artarak 4 milyon 644 bin kişi olmuştur (www.sbb.gov.tr). Ancak Türkiye'nin işgücü piyasasındaki işgücü (emek) arzında oluşan fazlalığı yani işsizliği, özel sektörün katkısı olmadan sadece kamu kaynaklarını kullanarak karşılayabilmesi ve azaltabilmesi mümkün görünmemektedir. Bunun en büyük göstergesi Tablo 2'de de görüldüğü üzere 2004-2018 yılları arasında KPSS'ye (Kamu Personeli 
Seçme Sınavı) giren aday sayısı ve aynı dönemde kamuda ilan edilen kadro sayısı arasındaki büyük dengesizliktir.

Tablo 2: Y1llara Göre KPSS'ye Giren Aday ve Merkezi Yerleştirmelerde İlan Edilen Kadro/Pozisyon Sayıları

\begin{tabular}{|c|c|c|}
\hline YILLAR* & $\begin{array}{c}\text { KPSS'YE GIREN } \\
\text { ADAY SAYISI }\end{array}$ & $\begin{array}{c}\text { ÍLAN EDILEN } \\
\text { KADRO/POZISYON } \\
\text { SAYISI }\end{array}$ \\
\hline 2004 & 1.731 .759 & 8.721 \\
\hline 2005 & 243.738 & 12.105 \\
\hline 2006 & 2.119 .569 & 21.411 \\
\hline 2007 & 299.734 & 23.494 \\
\hline 2008 & 2.408 .379 & 18.817 \\
\hline 2009 & 408.749 & 16.503 \\
\hline 2010 & 3.254 .086 & 20.476 \\
\hline 2011 & 412.984 & 25.299 \\
\hline 2012 & 3.504 .166 & 24.810 \\
\hline 2013 & 450.645 & 30.261 \\
\hline 2014 & 3.591 .042 & 19.799 \\
\hline 2015 & 603.447 & 15.372 \\
\hline 2016 & 5.806 .548 & 15.033 \\
\hline 2017 & 664.230 & 4.739 \\
\hline 2018 & 2.948 .424 & 3.201 \\
\hline \multicolumn{3}{|c|}{ TOPLAM } \\
\hline
\end{tabular}

*KPSS çift yıllarda B grubu, A grubu ve öğretmenlik kadroları için, tek yıllarda ise yalnızca A grubu ve öğretmenlik kadroları için yapılmaktadır.

Kaynak: http://www.dpb.gov.tr (Erişim Tarihi: 22.07.2019)

\section{Araştırmanın Yöntemi}

Çalışmada, süreçlerin ve olayların kendi sosyal bağlamında incelenmesi, toplumsal yaşamı değişkenlere veya sayılara çevirmeden anlamlandırma ve yorumlama çabası olarak ifade edilebilecek nitel araştırma yaklaşımı (Neuman, 2012:232-233) benimsenmiştir. Nitel araştırma, sosyal olguları bağlı oldukları ve içinde yer aldıkları ortamda doğal görünümleriyle gözlem, görüşme ya da belgeleri değerlendirmek yoluyla bilgi edinme ve bu bilgileri analiz ederek kuram geliştirme olarak tanımlanabilir (İslamoğlu, 2011:186). Nitel araştırmalarda amaç, incelenen olgu ya da kişi hakkında derinlemesine bilgi elde etmek, gelecekteki çalışmalar için fikirler oluşturmak veya bir olgu hakkında araştırmacının önsezilerini test etmektir (akt. Dedeoğlu, 2002:79).

Çalışmada kalitatif veri toplama yöntemlerinden olan derinlemesine mülakat yöntemi kullanılmıştır. Gençlerin girişimcilik eğilimlerini ve kariyer planlama süreçlerini anlamak ve yorumlamak için derinlemesine mülakat yöntemi ile kantitatif yöntemlere göre daha etkili sonuçlar elde edilebileceği öngörülmüştür. Bilindiği üzere derinlemesine mülakat yöntemi, belirli bir konuda bireylerle grup baskısına veya grup etkisine maruz kalmadan detaylı bir şekilde görüşme yapılmasıdır (Gegez, 2010:53).

Araştırmanın verileri, Mayıs ve Haziran 2019 tarihleri arasında Muğla Sıtkı Koçman Üniversitesi Sağlık Hizmetleri Meslek Yüksekokulu'nda toplanmıştır. Araştırma evrenini, yüksekokulun tüm öğrencileri oluşturmuştur. Yüksekokulun mevcut 4 farklı programından 
olmak üzere tamamen tesadüfi olarak ve araştırmaya katılmayı kabul eden, toplam 74 öğrenci araştırmanın örneklemini oluşturmuştur.

Türkiye'de meslek yüksekokullarının en önemli fonksiyonu, duyulan ihtiyaca göre bireylerin en kısa yoldan meslek sahibi olması ve iş hayatına atılmasının sağlanmasıdır. Ayrıca verilerin toplandığı Sağlık Hizmetleri Meslek Yüksekokulu'nda hem mezunları kamuda istihdam imkânı olan program öğrencileri (Tıbbi Laboratuvar Teknikleri ile Tıbbi Dokümantasyon ve Sekreterlik Programları) ve hem de kamuda istihdam imkânı olmayan program öğrencileri (Optisyenlik ile Tıbbi Tanıtım ve Pazarlama Programları) ile görüşülmüş olması, nitel araştırmalarda örneklemin temsil gücü için gerekli şartı sağlamaktadır.

Görüşmeler, bir görüşme formu üzerinden gerçekleştirilmiştir. Görüşme formunun geçerlik ve güvenilirliğini sağlamak için öncelikle iki öğrenci ile görüşülerek pilot görüşme yapılmıştır. Pilot çalışmadan sonra görüşme formunda gerekli görülen düzenlemeler yapılmıştır. Nihai hale getirilen görüşme formu, katılımcıların sosyo-demografik profilini belirlemeye yarayan toplam 7 soruluk ilk kısım ile katılımcıların en çok çalışmak istedikleri istihdam alanı, yapmak istedikleri mesleği seçme nedenleri, baba, anne ya da diğer yakınlarının meslek seçimleri üzerinde etkisi olup olmadığı, etkisi varsa yönlendirmelerinin hangi alanda olduğu, kendilerini girişimci bir kişiliğe sahip görüp görmedikleri, kendi işlerini kurmak isteyip istemedikleri, kendilerine göre girişimciliği engelleyen unsurların neler olduğu ve girişimciliği teşvik etmenin nasıl mümkün olabileceği ile ilgili görüşlerini belirlemeye yönelik yarı yapılandırılmış açık uçlu toplam 8 soruluk ikinci kısımdan oluşmaktadır.

Görüşmeler yüz yüze ve rahat bir iletişim için boş bir odada yapılmıştır. Öğrencilerin sorulara verdikleri cevaplara göre değişmekle birlikte her bir görüşme ortalama 30 dakika sürmüştür. Öğrencilerin verdikleri cevaplar anında görüşme formu üzerine aktarıldığı için ayrıca ses ve görüntü kaydına gerek duyulmamıştır.

Görüşmeler neticesinde elde edilen veriler içerik analizi yöntemi ile değerlendirilmiştir. İçerik analizi, yazılı belgelerde veya diğer iletişim ortamlarında yer alan bilgileri ve sembolleri, oluşturulan bir sisteme göre inceleme tekniğidir (Neuman, 2012:67). Görüşme formundaki bilgiler defalarca okunmuştur. Verilen cevaplar her bir kelime ve cümle değerlendirilerek sınıflandırılmıştır. Sonuç olarak sınıflandırılan tüm veriler analiz edilerek yorumlanmıştır.

Sosyal bilimlerde nitel araştırmaların önemli bir kısıtı olarak kabul edilen bulguların genellenememesi, bu çalışma için de söz konusudur. Ancak bu çalışmada kalitatif yöntemlerin gençlerin girişimcilik eğilimlerini ve kariyer planlama süreçlerini anlamak ve yorumlamak için kantitatif yöntemlerden daha etkili sonuçlar sunabileceği öngörülmüştür. Bunun yanında yapılan literatür taramasında konu ile ilgili yapılmış herhangi bir araştırmaya rastlanılmaması bu çalışmanın keşfedici yönüyle önemini arttırmaktadır.

\section{Araştırmanın Bulguları}

\subsection{Sosyo-Demografik Bulgular}

Katılımcı profilini gösteren cinsiyet, yaş, ailedeki çocuk sayısı, babanın mesleği, annenin mesleği, ailedeki aylık ortalama gelir düzeyi ve eğitim görülen program gibi katılımcıların sosyo-demografik özellikleri Tablo 3 'de topluca verilmiştir. 
Tablo 3: Katılımcıların Sosyo-Demografik Özellikleri

\begin{tabular}{|c|c|c|c|c|c|}
\hline Cinsiyet & Frekans & Yüzde & Baba Mesleği & Frekans & Yüzde \\
\hline Erkek & 34 & 45,9 & Memur & 17 & 23 \\
\hline Kadın & 40 & 54,1 & İşçi & 12 & 16,2 \\
\hline Toplam & 74 & 100 & Kendi iși & 18 & 24,3 \\
\hline Yaş & Frekans & Yüzde & Emekli & 17 & 23 \\
\hline 19 & 24 & 32,5 & Diğer & 10 & 13,5 \\
\hline 20 & 26 & 35,1 & Toplam & 74 & 100 \\
\hline 21 & 12 & 16,2 & Anne Mesleği & Frekans & Yüzde \\
\hline 22 & 6 & 8,1 & Memur & 10 & 13,5 \\
\hline 23 ve üstü & 6 & 8,1 & İşçi & 6 & 8,1 \\
\hline Toplam & 74 & 100 & Kendi işi & 4 & 5,4 \\
\hline Ailedeki Çocuk Sayısı & Frekans & Yüzde & Ev hanımı & 46 & 62,2 \\
\hline Tek çocuk & 12 & 16,2 & Emekli & 4 & 5,4 \\
\hline 2 kardeş & 24 & 32,5 & Diğger & 4 & 5,4 \\
\hline 3 kardeş & 18 & 24,3 & Toplam & 74 & 100 \\
\hline 4 kardeş & 12 & 16,2 & $\begin{array}{l}\text { Aile Ortalama } \\
\text { Gelir Düzeyi }\end{array}$ & Frekans & Yüzde \\
\hline 5 kardeş ve üstü & 8 & 10,8 & $2.020 \mathrm{TL}$ ve alt1 & 17 & 23 \\
\hline Toplam & 74 & 100 & $2.021-4.000 \mathrm{TL}$ & 32 & 43,2 \\
\hline $\begin{array}{l}\text { Eğitim Görülen } \\
\text { Program }\end{array}$ & Frekans & Yüzde & 4.001-6.000 TL & 18 & 24,3 \\
\hline Optisyenlik & 20 & 27 & 6.001TL ve üstü & 7 & 9,5 \\
\hline Tibbi Tanitım ve Paz. & 17 & 23 & Toplam & 74 & 100 \\
\hline $\begin{array}{l}\text { T1bbi Dokümantasyon } \\
\text { ve Sekreterlik }\end{array}$ & 18 & 24,3 & & & \\
\hline Tibbi Laboratuvar Tek. & 19 & 25,7 & & & \\
\hline Toplam & 74 & 100 & & & \\
\hline
\end{tabular}

Tablo 3’te de görüleceği üzere katılımcıların \%45,9'u erkek, \%54,1'i kadındır. \%32,5’i 19, \%35,1'i 20 yaşında olan katılımcıların \%16,2'si ailede tek çocuk iken, \%32,5'i 2 kardeş, \%24,3'ü 3 kardeş, \%16,2'si 4 kardeş, \%10,8'i ise 5 kardeş ve üstü kardeş olarak yaşamını sürdürmektedir. Araştırmaya katılan kişilerin baba mesleklerinin sırasıyla \%24,3 kendi işi, \%23 emekli, \%23 memur, \%16,2 işçi ve \%13,5 diğer meslekler olduğu görülmektedir. Katılımcıların annelerinin ise \%62,2 gibi çok büyük çoğunluk ile ev hanımı olduğu anlaşılmaktadır. Ailelerinin aylık ortalama gelir düzeylerine bakıldığında ise çoğunlukla 2.021-4.000 TL arasında aylık gelir düzeyine sahip katılımcı profili olduğu görülmektedir. Ayrıca ailelerindeki yetiştirilme tarzları sorulan katılımcılar çok büyük çoğunlukla yetiştirilme tarzlarını, kontrollü serbest veya güvene dayalı serbest olarak ifade etmişlerdir.

Katılımcılar, araştırmanın yapıldı̆̆ı Muğla Sıtkı Koçman Üniversitesi Muğla Sağlık Hizmetleri Meslek Yüksekokulu'nda aktif olarak eğitim öğretim faaliyetlerinin yürütüldüğü 4 programa kayıtlı olan öğrenciler olup, bu öğrencilerin \%27'si Optisyenlik, \%23’ü Tibbi Tanıtım ve Pazarlama, \%24,3'ü Tibbi Dokümantasyon ve Sekreterlik ile \%25,7'si Tibbi Laboratuvar Teknikleri Programı öğrencileridir.

\subsection{Derinlemesine Mülakat Bulguları}

Yapılan görüşmelerde meslek yüksekokulu öğrencilerine ilk olarak, görüşmenin yapıldığı an itibariyle en çok hangi sektörde veya alanda çalışmak istedikleri sorulmuştur. Aşağıda Tablo 4'de belirtildiği gibi katılımcıların \%44,5’i “en çok kamu sektöründe çalışmak istiyorum”, \%23'ü “en çok özel sektörde çalışmak istiyorum”, \%32,5’i ise "en çok kendi işimi kurmak istiyorum" şeklinde görüş belirtmişlerdir. 
Tablo 4: Eğitim Görülen Programlara Göre Katılımcıların Çalışmak İstedikleri Sektör/Alan

\begin{tabular}{|c|c|c|c|c|c|c|}
\hline & 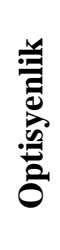 & 㝘 & 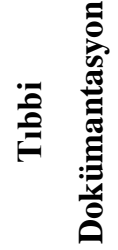 & 㝘 & 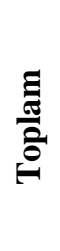 & 苋 \\
\hline $\begin{array}{r}\text { En çok kamu sektöründe } \\
\text { calısmak istiyorum }\end{array}$ & 2 & 2 & 14 & 15 & 33 & 44,5 \\
\hline $\begin{array}{l}\text { En çok özel sektörde } \\
\text { çalışmak istiyorum }\end{array}$ & 3 & 13 & - & 1 & 17 & 23 \\
\hline $\begin{array}{l}\text { En çok kendi işimi } \\
\text { kurmak istiyorum }\end{array}$ & 15 & 2 & 4 & 3 & 24 & 32,5 \\
\hline Toplam & 20 & 17 & 18 & 19 & 74 & 100 \\
\hline
\end{tabular}

Tablo 4'te de görüldüğü gibi, “En çok kamu sektöründe çalışmak istiyorum” şeklinde görüş bildiren katılımcıların büyük çoğunluğunun (29 kişi), mezunlarının kamuda istihdam imkânı olan Tıbbi Laboratuvar Teknikleri Programı ile Tıbbi Dokümantasyon ve Sekreterlik Programı'nın öğrencileri olduğu belirlenmiştir. Ayrıca bu öğrencilere, en çok kamu sektöründe çalışmak istemelerinin en önemli nedeni sorulduğunda, söylem sayısı bakımından şu şekilde verilen cevapların öne çıktığı görülmektedir:

- Ekonomik olarak daha iyi şartlara sahip olma isteği (garanti, sabit ve düzenli gelir vb.)

- Daha iyi çalışma şartları (belirli bir çalışma düzeni ve tatil olanaklarının fazla olması vb.)

- Riskin olmamas1

- Aile ve toplum baskis1

- Devlete hizmet etme isteği

"En çok özel sektörde çalışmak istiyorum” şeklinde görüş bildiren katılımcıların büyük çoğunluğunun ise (13 kişi), mezunları kamuda istihdam imkânı olmayan ancak mevzuata göre ilaç sektöründe çalışma imkânı bulunan Tıbbi Tanıtım ve Pazarlama Programı'nın öğrencileri olduğu belirlenmiştir. En çok özel sektörde çalışmak istemelerinin en önemli nedeni sorulduğunda da söylem sayısı bakımından şu şekilde verilen cevapların öne çıktığı görülmektedir:

- Daha fazla maddi kazanç elde etme isteği

- Kendi işini kurmadan önce tecrübe kazanma isteği

- Kariyer imkanlarının daha geniş ve tamamen kendime bağlı olması

- Özellikle birçok sektörün gelecek için firsatlar sunması ve kendisini geliştiren kişiler için geniş istihdam olanaklarına sahip olması

Yine Tablo 4’te de görüldüğü gibi, "En çok kendi işimi kurmak istiyorum” şeklinde görüş bildiren katılımcıların yarıdan fazlasının ise (15 kişi), mezunları kamuda istihdam imkânı olmayan ancak yürürlükteki meslek kanunu ile optik sektöründe geniş çalışma imkânı bulunan Optisyenlik Programı'nın öğrencileri olduğu belirlenmiştir. En çok kendi işini kurmak istemelerinin en önemli nedeni sorulduğunda ise söylem sayısı bakımından şu şekilde verilen cevapların öne çıktığı görülmektedir:

- Emir altında çalışmama ve kendi işinin patronu olma isteği 
- Daha iyi ekonomik şartlara sahip olma isteği (ücretli çalışanlara göre)

- İtibar ve tanınma isteği

- Kendi başına bir şeyler başarma isteği

Araştırmaya katılan öğrencilere meslek seçimleri konusunda anne, baba veya diğer yakınlarının herhangi bir etkisi, yönlendirmesi olup olmadığı sorulmuştur. Öğrencilerden sadece 21’i $(\% 28,4)$ hiçbir yakınının meslek seçimi üzerinde etkisinin olmadığını, 53'ü $(\% 71,6)$ ise anne, baba veya diğer yakınlarından en az birinin meslek seçimleri üzerinde etkisinin ve yönlendirmesinin olduğunu belirtmişlerdir.

Tablo 5’te görüldüğü üzere katılımcılardan 33 kişi babasının, 27 kişi annesinin, 33 kişi ise diğer yakınlarının (abi, abla, teyze, hala, amca ve arkadaş vb.) meslek seçimleri üzerinde etkisi ve yönlendirmesi olduğunu belirtmişlerdir. Yine Tablo 5'de de belirtildiği gibi anne, baba veya diğer yakınların, öğrencilerin meslek seçimi üzerindeki yönlendirmelerinin ağırlıklı olarak "kamu sektöründe çalışma" yönünde olduğu açıkça görülmektedir.

Tablo 5: Katılımcıların Yakınlarının Meslek Seçimleri Üzerindeki Etkisi

\begin{tabular}{|r|c|c|}
\hline & Evet & Hayır \\
\hline Babanızın, meslek seçiminiz üzerinde etkisi olur mu? & $\mathbf{3 3}$ & $\mathbf{4 1}$ \\
\hline Babam kamu sektöründe çalışmamı istiyor & 20 & \\
\hline Babam özel sektörde çalışmamı istiyor & 6 & \\
\hline Babam kendi işimi kurmamı istiyor & 7 & \\
\hline Annenizin, meslek seçiminiz üzerinde etkisi olur mu? & $\mathbf{2 7}$ & $\mathbf{4 7}$ \\
\hline Annem kamu sektöründe çalışmamı istiyor & 20 & \\
\hline Annem özel sektörde çalışmamı istiyor & 3 & \\
\hline Annem kendi işimi kurmamı istiyor & 4 & \\
\hline Diğer yakınlarınızın, meslek seçiminiz üzerinde etkisi olur mu? & 33 & $\mathbf{4 1}$ \\
\hline Yakınım kamu sektöründe çalışmamı istiyor & 17 & \\
\hline Yakınım özel sektörde çalışmamı istiyor & 7 & \\
\hline Yakınım kendi işimi kurmamı istiyor & 9 & \\
\hline Meslek Seçimimde Hiçbir Yakınımın Etkisi Yok Diyen Katılımcı Sayısı: 21 Kişi \\
\hline
\end{tabular}

Görüşmenin yapıldı ̆̆ 1 an itibariyle en çok kamu sektöründe çalışmak istediğini belirten 33 katılımcının yakınlarının, meslek seçimleri ile ilgili yönlendirmelerinin hangi yönde olduğu Tablo 6'da ayrıntılı olarak gösterilmiştir. Görüldüğü gibi sadece 6 katılımcı, hiçbir yakınının etkisi altında kalmadan kamu sektöründe çalışmak istediğini beyan etmiştir. 27 katılımcı ise yakınlarının ağırlıklı olarak kamu sektöründe çalışma yönündeki yönlendirmeleri ile kamu sektöründe çalışmak istediğini beyan etmiştir. 
Tablo 6: En Çok Kamu Sektöründe Çalışmak İsteyen Katılımcıların, Yakınlarının Meslek Seçimlerine Etkisi

\begin{tabular}{|r|c|c|c|}
\hline & Kamu & Özel & Kendi İşi \\
\hline Baba & 20 & - & - \\
\hline Anne & 20 & - & - \\
\hline Diğer Yakınlar & 17 & - & Yakınlarımın Etkisi Yok Diyen Katılımcı Sayısı: 6 Kişi \\
\hline \multicolumn{5}{|r|}{ En çok kamu sektöründe çalışmak istiyorum diyen katılımcı sayısı: 33 Kişi }
\end{tabular}

Görüşmenin yapıldığı an itibariyle en çok özel sektörde çalışmak istediğini belirten 17 katılımcının yakınlarının, meslek seçimleri ile ilgili yönlendirmelerinin hangi yönde olduğu Tablo 7'de ayrıntılı olarak gösterilmiştir. Görüldüğü gibi 6 katılımcı, hiçbir yakınının etkisi altında kalmadan özel sektörde çalışmak istediğini beyan etmiştir. 11 katılımcı ise yakınlarının özel sektörde çalışma yönündeki yönlendirmeleri ile özel sektörde çalışmak istediğini beyan etmiştir.

Tablo 7'de görüldüğü gibi özel sektörde çalışmak isteyenlerin yakınlarının ağırlıklı olarak yönlendirmeleri, kendi işlerini kurmaları yönündedir. Özel sektörde çalışmak istediğini belirten katılımcılara, yakınlarının kendi işlerini kurmaları yönündeki yönlendirmelerine rağmen niçin özel sektörde çalışmak istedikleri sorulduğunda, özellikle Tıbbi Tanıtım ve Pazarlama Programı ile Optisyenlik Programı öğrencilerinin kendi işlerini kurmak için girişimde bulunmadan önce meslekleri ile ilgili tecrübe kazanmak için sektörlerinde çalışmak istediklerini beyan etmişlerdir.

Tablo 7: En Çok Özel Sektörde Çalışmak İsteyen Katılımcıların, Yakınlarının Meslek Seçimlerine Etkisi

\begin{tabular}{|r|c|c|c|}
\hline & Kamu & Özel & Kendi İşi \\
\hline Baba & 3 & 6 & 8 \\
\hline Anne & 1 & 3 & 9 \\
\hline Diğer Yakınlar & - & 7 & 5 \\
\hline \multicolumn{3}{|c|}{ Yakınlarımın Etkisi Yok Diyen Katılımcı Sayısı: 6 Kişi } \\
\hline
\end{tabular}

Görüşmenin yapıldığı an itibariyle en çok kendi işini kurmak istediğini belirten 24 katılımcının yakınlarının, meslek seçimleri ile ilgili yönlendirmelerinin hangi yönde olduğu Tablo 8'de ayrıntılı olarak gösterilmiştir. Görüldüğü gibi 9 katılımcı, hiçbir yakınının etkisi altında kalmadan kendi işini kurmak istediğini beyan etmiştir. 15 katılımcı ise yakınlarının kendi işini kurma yönündeki yönlendirmeleri ile kendi işini kurmak istediğini beyan etmiştir. 
Tablo 8: En Çok Kendi İşini Kurmak İsteyen Katılımcıların, Yakınlarının Meslek Seçimlerine Etkisi

\begin{tabular}{|r|c|c|c|}
\hline & Kamu & Özel & Kendi İşi \\
\hline Baba & 3 & - & 7 \\
\hline Anne & 3 & 1 & 9 \\
\hline Diğer Yakınlar & 5 & - & 4 \\
\hline \multicolumn{3}{|r|}{ Yakınlarımın Etkisi Yok Diyen Katılımcı Sayısı: 9 Kişi } \\
\hline
\end{tabular}

Yapılan görüşmelerde son olarak meslek yüksekokulu öğrencilerine kendilerini girişimci bir kişiliğe sahip olarak görüp görmedikleri, yaşamlarının bir döneminde girişimci olmak ve kendi işlerini kurmak isteyip istemedikleri sorulmuştur. Katılımcılar tarafindan verilen cevaplar, Tablo 9' da topluca verilmiştir. Katılımcılardan 45 kişi $(\% 60,8)$ kendisini girişimci bir kişiliğe sahip olarak tanımlarken, 24 kişi $(\% 32,5)$ girişimci bir kişiliğe sahip olmadığını, 5 kişi $(\% 6,7)$ ise bu konuda kararsız olduğunu beyan etmiştir.

Tablo 9: Katılımcıların Girişimci Olma İsteği

\begin{tabular}{|r|c|c|c|}
\hline & Evet & Hayır & Kararsızım \\
\hline Kendinizi girişimci bir kişiliğe sahip görüyor musunuz? & 45 & 24 & 5 \\
\hline Girişimci olmak ve kendi işinizi kurmak ister misiniz? & 48 & 13 & 13 \\
\hline
\end{tabular}

Katılımcılardan 48 kişi (\%65) yaşamlarının bir döneminde girişimci olmak ve kendi işlerini kurmak istediklerini belirtmişlerdir. "Niçin şimdi değil de gelecekte" sorusuna verilen cevaplarda öne çıkanlar ise şu şekilde sıralanabilir:

- Şu an için maddi olarak yeterli imkana sahip değilim

- Şu an için kendimi yeterli tecrübeye sahip olarak görmüyorum

- Yakınlarımdan maddi ve manevi destek alamıyorum

- Şu an için özgüvenim eksik, risk alamam

- Ailem teşvik edici yapıda değil

\section{Sonuç ve Öneriler}

Bu çalışmanın amacı, gençlerin kariyer planlarını, kendi istekleri veya anne, baba ya da diğer yakınlarının baskısı ile kamuda istihdam edilme üzerine kurmalarının, girişimcilik eğilimleri üzerinde etkisinin olup olmadığını belirlemektir. Nitel araştırma yaklaşımının benimsendiği bu çalışma, genelleştirilememekle birlikte örneklem olarak mezunları hem kamuda istihdam imkânı olan hem de kamuda istihdam imkânı olmayan program öğrencileri ile görüşülmüş olması itibarıyla, gençlerin girişimcilik eğilimlerini ve kariyer planlama süreçlerini anlamak ve yorumlamak için yararlı sonuçlar ortaya koymuştur.

Mezunlarının kamuda istihdam imkanı olan Tıbbi Laboratuvar Teknikleri Programı ile Tıbbi Dokümantasyon ve Sekreterlik Programı öğrencilerinin, ağırlıklı olarak kamu sektöründe çalışmayı istedikleri, mezunlarının kamuda istihdam imkanı olmayan ancak mevzuata göre ilaç sektöründe çalışma imkanı bulunan Tıbbi Tanıtım ve Pazarlama Programı öğrencilerinin ağırlıklı olarak özel sektörde çalışmak istedikleri, yine mezunlarının kamuda istihdam imkanı olmayan ancak yürürlükteki meslek kanunu ile optik sektöründe geniş çalışma imkanı bulunan Optisyenlik Programı öğrencilerinin ise ağırlıklı olarak kendi işlerini kurmak istedikleri 
belirlenmiştir. Bu bulgulara göre aldıkları eğitimin bireyleri girişimciliğe yönlendirebileceği ve üniversite öğrencilerinin eğitim gördükleri alana göre girişimcilik eğilimlerinde farklılıklar olabileceği görülmektedir. Üniversite öğrencilerinin eğitim gördükleri alana göre girişimcilik eğilimlerinin bazı alt boyutlarında farklılıkların belirlendiği Marangoz ve diğ. (2013) tarafından yapılan araştırma sonuçlarına benzer şekilde bu sonuç, gençlerin eğitim gördükleri alan ile girişimcilik eğilimleri arasında ilişki kurulabileceğini göstermektedir.

Katılımcılardan sadece $21^{\prime} \mathrm{i}(\% 28,4)$ hiçbir yakınının meslek seçimi üzerinde etkisinin olmadığını, 53'ü $(\% 71,6)$ ise anne, baba veya diğer yakınlarından en az birinin meslek seçimleri üzerinde etkisinin ve yönlendirmesinin olduğunu belirtmişlerdir. Buna göre gençlerin meslek seçimleri ve kariyer planları üzerinde anne, baba ve diğer yakınlarının önemli bir etkisinin olduğu sonucuna varılabilir.

Kamu sektöründe çalışmak istediğini belirten toplam 33 katılımcıdan 27'si anne, baba veya diğer yakınlarının ağırlıklı olarak kamu sektöründe çalışma yönündeki yönlendirmeleri ile kamu sektöründe çalışmak istediğini beyan etmiştir. Kariyerini kamuda istihdam edilme üzerine planlayan gençlerin ağırlıklı olarak yakınlarının yönlendirmelerinden etkilendiği görülmektedir.

Katılımcıların \%60,8'i (45 kişi) kendisini girișimci bir kişiliğe sahip olarak görürken ve \%65'i (48 kişi) yaşamının bir döneminde girişimci olmak ve kendi işini kurmak istediğini belirtirken sadece \%32,5'i (24 kişi), araştırmanın yapıldığ 1 an itibarıyla kendi işini kurmak istediğini beyan etmiştir. Bu bulgulara göre gençlerin zihinsel olarak girişimcilik eğiliminde olsalar bile yeterli maddi imkana ve tecrübeye sahip olmamak, yakınlarından maddi ve manevi destek alamamak, özgüven eksikliği ve ailenin teşvik edici yapıda olmaması gibi nedenlerle kendi işini kurma kararlarını ileriki bir tarihe öteledikleri görülmektedir.

$\mathrm{Bu}$ durumda genel olarak gençlerin tek başlarına girişimci olmaya karar vermeleri mümkün görünmemektedir. Herkesin kamuda istihdam edilmesinin mümkün olmadığı bir ülke olarak Türkiye'de gençlerin kendi işini kurabilmeleri için yakın aile üyeleri tarafından cesaretlendirilmeleri, maddi ve manevi olarak teşvik edilmelerinin önemi ortaya çıkmaktadır.

İş dünyasında meydana gelen ekonomik, teknolojik ve sosyolojik değişimlerle birlikte bireylerin gelecek kaygıları her geçen gün artmaktadır. Her alanda yaşanan hızlı değişim, bireylerin kariyer planlaması yapmalarını zorunlu kılmaktadır (Esmer ve Pabuçcu, 2019:113). İstihdam edilemeyen binlerce mezunu bulunan bölüm ve programların hala gençlerimiz tarafından tercih ediliyor olması ve hali hazırdaki bu bölüm ve programlara hala yenilerinin ilave ediliyor olması, planlamaya ne kadar çok ihtiyaç olduğunun göstergeleridir.

İşsizliğin azaltılması için nüfus artışı, iç ve dış göçler, yetersiz gelir düzeyi, teknolojik gelişmeler, bölgeler arası gelişme farklılıkları, yatırım politikalarının olumsuzlukları, eğitim politikalarındaki sorunlar gibi makro ölçekli yapısal nedenler dışında (Karabulut, 2007:20), iş gücü piyasasına katkı sunan tüm kurum ve kuruluşların kendi görev alanı veya görev tanımları ile ilgili, iş gücü piyasasında herhangi bir israfa yol açmayan yeni stratejiler belirlemesi gerekmektedir. 


\section{Kaynakça}

Akgün, İ. ve Akgün, A. A. (2017), “İstanbul'da İstihdam Eğilimlerinin Belirlenmesi”, Marmara Üniversitesi Yayınları (Yayın No: 851), http://katalog.marmara.edu.tr/muyayinevi/ YN851.pdf (Erişim Tarihi: 18.08.2019).

Aksel, İ. ve Bağcı, Z. (2016), "Girişimcilik Eğilimi; Bir Kamu Üniversitesinin İİBF'sinde Öğrenim Gören Son Sınıf Öğrencilerinde Bir Araştırma”, İnsan ve Toplum Bilimleri Araştırmaları Dergisi, Cilt:5, Sayı:7, s.2120-2133.

Aytaç, Ö. ve İlhan, S. (2007), "Girişimcilik ve Girişimci Kültür: Sosyolojik Bir Perspektif”, Selçuk Üniversitesi Sosyal Bilimler Dergisi, Sayı:18, s.101-120.

Basim, H. N. ve Şeşen, H. (2012), "Demografik Faktörler ve Kişiliğin Girişimcilik Niyetine Etkisi: Spor Bilimleri Alanında Öğrenim Gören Üniversite Öğrencileri Üzerine Bir Araştırma”, Ege Akademik Bakış Dergisi, Cilt: 12, Özel Sayı, s. 21-28.

Bozkurt, Ö. ve Erdurur, K. (2013), "Girişimci Kişilik Özelliklerinin Girişimcilik Eğilimindeki Etkisi: Potansiyel Girişimciler Üzerinde Bir Araştırma”, Girişimcilik ve Kalkınma Dergisi, Cilt:8, Say1:2, s.57-78.

Börü, D. (2006), "Girişimcilik Eğilimi, Marmara Üniversitesi İşletme Bölümü Öğrencileri Üzerine Bir Araştırma", Marmara Üniversitesi Yayınları (Yayın No: 733), http://www.academia.edu (erişim tarihi:18.06.2017).

Can, H., Aşan Ö. ve Aydın E. M. (2006), “Örgütsel Davranış”, Arıkan Basım Yayım, İstanbul. Çolakoğlu, N., Gözükara İ. (2016), "A comparison study on personality traits based on the attitudes of university students toward entrepreneurship”, Procedia Social and Behavioral Sciences, Vol.229, s.133-140.

Dedeoğlu, A. Ö. (2002), "Tüketici Davranışları Alanında Kalitatif Araştırmaların Önemi Ve Multidisipliner Yaklaşımlar", D.E.Ü.İ.İ.B.F. Dergisi Cilt:17 Sayı:2, s.75-92.

Esmer, Y. ve Pabuçcu, H. (2019), "Stratejik Kariyer Planlama: Bulanık Mantık Yaklaşımı", İzmir İktisat Dergisi, Cilt: 34 Say1: 1, s. 111-124.

Gegez, A. E. (2010), “Pazarlama Araştırmaları”, (3. Bask1), Beta Yayınları, İstanbul.

Gurel, E., Altinay, L. ve Daniele, R. (2010), “Tourism Students’ Entrepreneurial Intentions” Annals of Tourism Research, 37(3):646-669.

İraz, R. (2010), "Yaratıcılık ve Yenilik Bağlamında Girişimcilik ve Kobiler”, Çizgi Kitapevi, Konya.

İslamoğlu, A. H. (2011), “Sosyal Bilimlerde Araştırma Yöntemleri”, (2. Baskı), Beta Yayınları, İstanbul.

Karabulut, A. (2007), “Türkiye’deki İşsizliği Önlemede Aktif İstihdam Politikalarının Rolü ve Etkinliği”, Çalışma ve Sosyal Güvenlik Bakanlığı Uzmanlık Tezi. https://statik.iskur.gov.tr/tr/rapor_bulten/uzmanlik_tezleri/ALPASLAN\%20KARABUL U.pdf (erişim tarihi:11.06.2019).

Kiliç, R., Keklik, B. ve Çaliş, N. (2012), "Üniversite Öğrencilerinin Girişimcilik Eğilimleri Üzerine Bir Araştırma: Bandırma İİBF İşletme Bölümü Örneği”, Süleyman Demirel Üniversitesi İktisadi ve İdari Bilimler Fakültesi Dergisi, Cilt:17, Sayı:2, s.423-435.

Koh, H. C. (1996), "Testing hypotheses of entrepreneurial characteristics A study of Hong Kong MBA students”, Journal of Managerial Psychology, Vol.11, s.12-25.

Korkmaz, O. (2012), “Üniversite Öğrencilerinin Girişimcilik Eğilimlerini Belirlemeye Yönelik Bir Araştırma: Bülent Ecevit Üniversitesi Örneği”, Afyon Kocatepe Üniversitesi İktisadi ve İdari Bilimler Fakültesi Dergisi, Cilt:14, Sayı:2, s.209-226.

Marangoz, M. (2016), "Girişimcilik” (3. Baskı), Beta Yayınları, İstanbul.

Marangoz, M., Kaya, F., Bakan, H. (2013), "Eğitim Alanı Girişimcilik Niyetini Nasıl Etkilemektedir? Üniversite Öğrencilerine Yönelik Bir İnceleme", Uluslararası Girişimcilik ve Kariyer Sempozyumu Bildiri Kitabı. 
Neuman, W. L. (2012), “Toplumsal Araştırma Yöntemleri Nitel ve Nicel Yaklaşımlar” 2.Cilt, (5. Baskı), Yayın Odası Yayınevi, Ankara.

Top, S. (2008), "İ̧̧letmelerde Yenilik ve Yaratıcılık Yönetimi”, Beta Yayınları, İstanbul.

Yilmaz, E. ve Sünbül, M. A. (2009), "Üniversite Öğrencilerine Yönelik Girişimcilik Ölçeğinin Geliştirilmesi”, Selçuk Üniversitesi Sosyal Bilimler Enstitüsü Dergisi, Sayı:21, s.195201.

http://www.tuik.gov.tr (Erişim Tarihi: 22.03.2020).

http://www.sbb.gov.tr/kamu-istihdami/ (Erişim Tarihi: 19.03.2020).

http://www.dpb.gov.tr/tr-tr/istatistikler (Erişim Tarihi: 22.07.2019).

https://www.kosgeb.gov.tr/ (Erişim Tarihi: 15.07.2019). 